\title{
Rapid Determination of Sucrose in Fruit Juices: A New Sensitive Carbon Nanotube Paste Osmium-Polymer Mediated Biosensor
}

\author{
Riccarda Antiochia ${ }^{1}$, Lo Gorton ${ }^{2} \&$ Luisa Mannina ${ }^{1}$ \\ ${ }^{1}$ Department of Chemistry and Drug Technologies, Sapienza University of Rome, Piazz.le A. Moro 5, 00185 \\ Rome, Italy \\ ${ }^{2}$ Department of Analytical Chemistry/Biochemistry and Structural Biology, Lund University, P. O. Box 124, \\ SE-221 00 Lund, Sweden \\ Correspondence: Riccarda Antiochia, Department of Chemistry and Drug Technologies, Sapienza University of \\ Rome, Piazzale Aldo Moro 5, 00185 Rome, Italy. Tel: 39-06-4976-6514. Fax: 39-06-4457050. E-mail: \\ riccarda.antiochia@uniroma1.it
}

Received: June 10, 2013 Accepted: December 10, 2013 Online Published: May 5, 2014

doi:10.5539/jfr.v3n4p101 URL: http://dx.doi.org/10.5539/jfr.v3n4p101

\begin{abstract}
The aim of the present work was the development of a novel amperometric biosensor for rapid detection of sucrose in fruit juices samples. Two enzymes, invertase and fructose dehydrogenase (FDH), were immobilized onto a single-walled carbon nanotube paste (SWCNTP) electrode by wiring with a highly original osmium-polymer hydrogel. A second biosensor, for fructose only, was constructed containing inactive invertase and used for signal subtraction.

The biosensor exhibits a detection limit for sucrose of $2 \mu \mathrm{M}$, linearity up to $5 \mathrm{mM}$, good sensitivity of $1.98 \mu \mathrm{A}$ $\mathrm{cm}^{-2} \mathrm{mM}$, good reproducibility (RSD $=2.5 \%$ ), fast response time $(8 \mathrm{~s})$ and a stability of 4 months if kept under wet conditions at $4{ }^{\circ} \mathrm{C}$.

The biosensor was successively tested for specific detection of sucrose and fructose in several commercial fruit juice samples and the results were compared with those obtained with a commercial spectrophotometric enzymatic kit.
\end{abstract}

Keywords: sucrose, fruit juices, biosensor, invertase, fructose dehydrogenase, osmium redox polymer

\section{Introduction}

Sucrose is an important monosaccharide contained in many foodstaffs and sweet drinks. The determination of sucrose is therefore extremely important for food and beverage industries where quality control is essential for both consumer protection and for food industries. Various conventional analytical methods are largely reported in literature for the determination of sucrose, such as gas-chromatography, UV-spectrophotometry, titration and electrophoresis (AOAC, 1995; Beutler, 1984). However, all these methods require expensive instrumentation, long time of analysis, well trained operators and sometimes also complicated sample pretreatments. It is therefore of extreme importance to develop a fast, selective and affordable method usable by food industries. Biosensors can represent a unique alternative: they are low cost devices with very good sensitivity and selectivity which can be easily used "in situ" without long or difficult sample pretreatments (Tran \& Cahn, 1993; Eggins, 2002; Wagner \& Guilbault, 1994).

Sucrose biosensors are generally based on the activity of either invertase, mutarotase and glucose oxidase (GOx) (Boyaci \& Mutlu, 2002; Mizutani \& Yabuki, 1997) or sucrose phosphorylase, phosphoglucomutase and glucose-6-phosphate-1-dehydrogenase (GDH) (Boyaci \& Mutlu, 2002). Protein layer (Majer-Baranyi, Adanyi, \& Varadi, 2008), graphite paste (Kennedy, Pimentel, Melo, \& Lima-Filho, 2007), clay matrix (Mohammadi, Amine, Cosner \& Mousty, 2005) and Prussian blue (Haghighi, Vaina, Alizadeh, Yigzaw, \& Gorton, 2004) were generally utilized for enzymes immobilization (Mutlu, 2011). With these sensors, the current signal is related to either oxygen consumption or hydrogen peroxide production in the case of GOx or to the reoxidation of a proper mediator with the concomitant use of the diaphorase enzyme for the reoxidation of the produced NADPH in the case of GDH (Mutlu, 2011). However, these methods are laborious and time-consuming because a cascade of three or four enzyme system with consequent problems of reproducibility and stability. 
We propose a more convenient method which used only two enzymes, invertase and fructose dehydrogenase, immobilized onto a single-walled carbon nanotube paste (SWCNTP) electrode properly modified with a highly original osmium-polymer hydrogel.

Fructose dehydrogenase (FDH; E.C. 1.1.99.11) was first studied by Ameyama and Adachi (1982). It catalyses the oxidation of fructose to 5-keto-D-fructose without the addition of the well-known $\mathrm{NAD}(\mathrm{P})^{+} / \mathrm{NAD}(\mathrm{P}) \mathrm{H}$ cofactor, generally required by dehydrogenase enzymes, by using the bound cofactor flavin adenine dinucleotide (FAD) (Ameyama et al., 1982; Kamitaka, Tsujimura, Setoyama, Kajno, \& Kano, 2007) which is reduced to $\mathrm{FADH}_{2}$.

Invertase enzyme (E.C. 3.2.1.26) catalyzes the hydrolysis of sucrose to glucose and fructose. The coupling of the two enzymes can be therefore succesfully utilized for the construction of the sucrose biosensor (Clanek, Vydano, \& Braunovà, 2000).

The development and the use of new nanomaterials have been revolutionizing the area of biosensors. Among the nanomaterials, carbon nanotubes have started to be used in electrochemistry as electrode material for biosensor development because of their extraordinary electrochemical properties (Valentini, Amine, Orlanducci, Terranova, \& Palleschi, 2003; Antiochia, Lavagnini, Magno, Valentini, \& Palleschi, 2004a; Antiochia, Lavagnini, \& Magno, 2005). Their easy preparation and the possibility of renewal of their surface allowed the carbon nanotube paste (CNTP) electrodes to become popular for electrode modification (Gooding, 2005; Wang, 2005; Antiochia, Lavagnini, \& Magno, 2004b).

The aim of the present work is to develop a novel biosensor for sucrose determination by using a CNTP electrode modified with an osmium redox polymer. The osmium redox polymer showed excellent electron shuttling properties and for this reason it was successfully used for the electrical wiring of cells and enzymes (Timur, Haghighi, Tkac, Pazarlioglu, Telefoncu, \& Gorton, 2006a; Timur, Yigzae, \& Gorton, 2006b; Antiochia, Vinci \& Gorton, 2013) and for biosensor and biofuel cells development (Antiochia \& Gorton, 2007; Heller, 1992; Heller \& Feldman, 2008).

The osmium redox polymer in the present paper was used for a dual function: redox mediator to shuttle the electrons between the immobilized enzyme and the electrode and support for direct wiring of both invertase and FDH into the paste by utilizing a cross-linking agent, poly(ethylene glycol) diglycidyl ether (PEDGE).

The proposed biosensor was finally tested for sucrose analysis in real fruit juice samples and the results obtained were validated by comparing the results with a standard spectrophotometric kit.

\section{Materials and Methods}

\subsection{Reagents}

Invertase (E.C. 3.2.1.26) from baker's yeast, fructose dehydrogenase (FDH) (E.C. 1.1.1.47) from Gluconobacter sp., sucrose and D-fructose were obtained from Sigma (St. Louis, MO, USA), poly(ethylene glycol) (400) diglycidyl ether (PEDGE) from Polyscience (Warrington, PA, USA); poly(1-vinylimidazole) $)_{12}$-[osmium(4,4'-dimethyl-2,2'-dipyridyl $\left.)_{2} \mathrm{Cl}_{2}\right]^{2+/+}$ (osmium redox polymer) was provided from ThereSense Inc. (Alameda, CA, USA); single-walled carbon nanotubes (SWCNT) (diameter 1-2 $\mu \mathrm{m}$ ) were purchased from Aldrich (Steinheim, Germany) and mineral oil from Fluka (Buchs, Switzerland). All other reagents were analytical grade from Carlo Erba (Milan, Italy). All solutions were made with high purity water (Milli-Q System, Millipore, Bedford, MA, USA).

\subsection{Preparation of the SWCNTP Electrode Modified With Os-polymer}

The SWCNTP electrodes were prepared by hand-mixing in a mortar SWCNTs and mineral oil at a $60: 40 \%$ ratio (w/w) (Valentini et al., 2003) and packed into a cavity ( $3 \mathrm{~mm}$ diameter). A copper wire connected to the paste allowed the electrical contact.

The CNTP electrode was modified with Os-polymer by depositing $10 \mu \mathrm{L}$ of a solution $(10 \mathrm{mg} / \mathrm{mL})$ of the Os-polymer and $1 \mu \mathrm{L}$ of an aqueous solution $(2.5 \mathrm{mg} / \mathrm{mL})$ of the cross-linker agent PEDGE (Antiochia et al., 2007) onto the CNTP electrode surface. The electrodes were then left to dry overnight at room temperature.

\subsection{Preparation of the Sucrose Biosensor}

Invertase and FDH were directly wired into the Os-polymer hydrogel by mixing $10 \mu \mathrm{L}$ of the Os-polymer solution $(10 \mathrm{mg} / \mathrm{ml}), 1 \mu \mathrm{L}$ of an aqueous solution of PEDGE $(2.5 \mathrm{mg} / \mathrm{mL}), 10 \mu \mathrm{L}$ of a solution containing 5 units of FDH enzyme and $10 \mu \mathrm{L}$ of a solution containing 5 units of invertase enzyme. Then $10 \mu \mathrm{L}$ of this solution was deposited onto the CNTP electrode surface and allowed to dry overnight (Antiochia et al., 2007). Figure 1 shows the wiring of invertase and FDH through the Os-polymer redox hydrogel onto the SWCNTP electrode. 


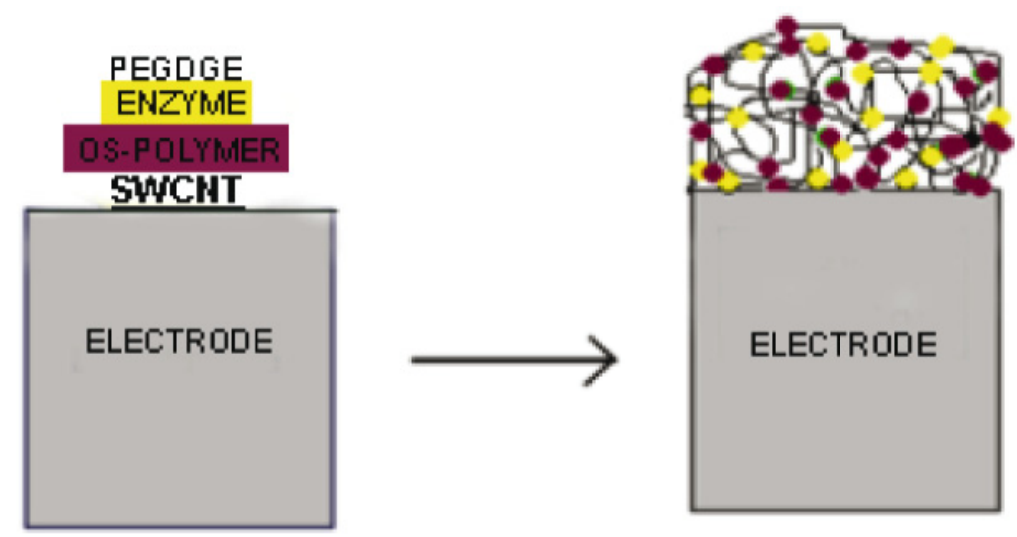

Figure 1. Scheme of the inveratse-FDH wiring through redox hydrogel of Os-polymer onto CNTP electrode

A second biosensor, for fructose only, was constructed following the same procedure containing inactive invertase and used for signal subtraction.

Successively, aliquots of a stock solution of sucrose in $0.1 \mathrm{M}$ acetate buffer at $\mathrm{pH} 5.0$ were added in the electrochemical cell and the corresponding steady-state current, achieved in about 20-25 seconds, after each adding. The steady-state current was achieved within 20-25 s.

\subsection{Electrochemical Equipment}

Electrochemical experiments were carried out using an Autolab electrochemical system with PGSTS-12 (GPES software) supplied by Eco Chemie (Utrecht, The Netherlands). The electrochemical cell consists of three electrodes, the modified CNTP electrode (3 mm diameter) as working electrode, an $\mathrm{Ag} \mid \mathrm{AgCl} / \mathrm{KCl}(\mathrm{sat})$ as reference and a platinum wire as counter electrode. The electrochemical cell contained $10 \mathrm{~mL}$ of $0.1 \mathrm{M}$ phosphate buffer or $0.1 \mathrm{M}$ acetate buffer at different $\mathrm{pHs}$. The amperomeyric experiments were carried out at a fixed potential of $+200 \mathrm{mV}$ versus $\mathrm{Ag} \mid \mathrm{AgCl}$ at room temperature.

\subsection{Application in Food Analysis}

The assembled biosensor was tested for the analysis of sucrose and fructose content in commercial fruit juices. The sucrose concentration values of the real samples were extrapolated from the calibration curve obtained for the standard sucrose solution. As fructose content present in the samples causes interference with sucrose determination, the fructose content was previously measured with the biosensor with inactive invertase and the current signal was subtracted from the total current response of the sucrose biosensor.

The sucrose content was determined also with the enzymatic spectrophotometric assay kit (Mannheim, Germany, Cat.N.139106) where the amount of sucrose is related to the amount of NADPH formed during th enzymatic reaction and detected spectrophotometrically at $340 \mathrm{~nm}$.

Fruit juices samples did not require any pretreatment. For the analysis of the beverage samples $50 \mu \mathrm{L}$ of each sample were directly added to the electrochemical cell containing $10 \mathrm{~mL}$ of buffer.

\section{Results and Discussion}

The operating mechanism of the sucrose biosensor is represented by the following reactions:

Invertase

$$
\begin{gathered}
\text { sucrose }+\mathrm{H}_{2} \mathrm{O} \longrightarrow \alpha \text {-D-glucose }+\mathrm{D} \text {-fructose } \\
\text { D-fructose }+2 \mathrm{Os}^{3+} \stackrel{\text { FDH }}{\rightarrow} \text { 5-keto-D-fructose }+2 \mathrm{H}^{+}+2 \mathrm{Os}^{2+} \\
2 \mathrm{Os}^{2+} \underset{+200 \mathrm{mV} \text { vs. Ag/AgCl }}{\stackrel{\text { CNTP electrode }}{\longrightarrow}} 2 \mathrm{Os}^{3+}+2 \mathrm{e}^{-}
\end{gathered}
$$

Sucrose is converted to D-fructose (reaction 1) which is then oxidized to 5-keto-D-fructose by FDH (reaction 2). The reduced osmium complex is now reoxidized at the CNTP electrode at a fixed potential of $+200 \mathrm{mV}$ (reaction 3). The enzymatic reaction generates current responses which are proportional to the sucrose concentration. this 
is valid for sucrose concentration values lower than the Michaelis-Menten constant. The oxygen independent biosensor (Davidson \& Jones, 1991) is based on a very simple mechanism due to the fact that FDH enzyme contains FAD as cofactor and does not require the adding of the most common used $\mathrm{NAD}^{+}$required by most other dehydrogenase enzymes. Figure 2 shows the stucture of the osmium mediator.

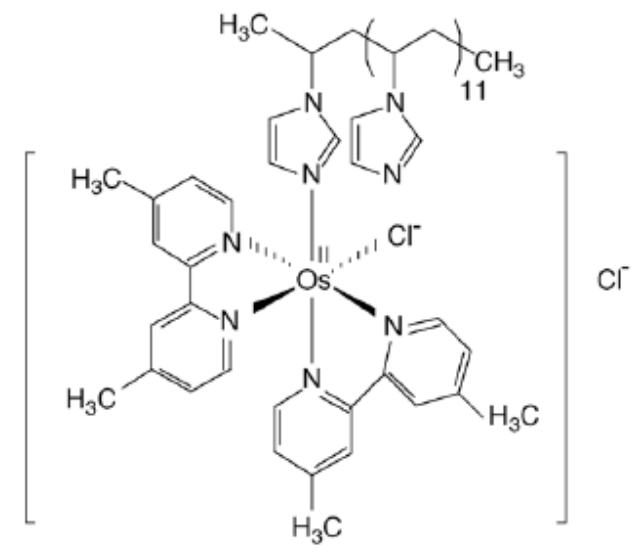

Figure 2. Chemical structure of poly(1-vinylimidazole) 12 -[osmium(4,4'-dimethyl-2,2'-bipyridyl $\left.{ }_{2} \mathrm{Cl}_{2}\right]_{2}+/+$ (osmium redox polymer)

\subsection{Electrochemical Properties of Invertase/FDH/Os-polymer/CNTP Electrode}

An electrochemical study of a similar Os-polymer CNTP modified electrode was already reported in our previous work (Antiochia et al., 2007). Figure 3 shows cyclic voltammograms recorded at a scan rate of $10 \mathrm{mV} / \mathrm{s}$ in the absence and in the presence (curves a and b, respectively) of invertase and FDH enzymes. All voltammograms clearly showed the typical behavior of surface-bound species with small peak separations thus demonstrating that the presence of invertase and FDH enzymes does not change the electrochemical behavior of the modified electrode. From the voltammetric curve it has been calculated a formal redox potential of the Os-polymer of about $+180 \mathrm{mV}$ vs. $\mathrm{Ag} \mid \mathrm{AgCl}$, value which is in perfect agreement with the value previously reported in literature (Timur et al., 2006a; Timur et al., 2006b; Antiochia et al., 2007). Therefore the working potential of the biosensor was choosen at $+200 \mathrm{mV}$ for further experiments.

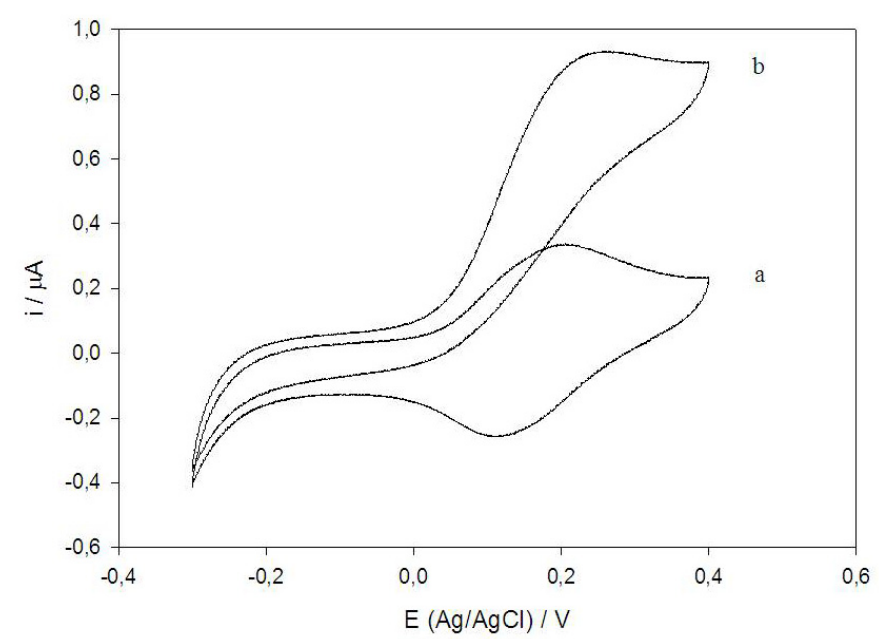

Figure 3. Cyclic voltammograms of the invertase-FDH-Os-polymer modified CNTP electrode in the absence (curve a) and in the presence of $5 \times 10^{-3} \mathrm{M}$ sucrose concentration (curve b). Experimental conditions: applied potential: $0.2 \mathrm{~V}$ (vs. $\mathrm{Ag} / \mathrm{AgCl}$ ); Os-polymer: $10 \mu \mathrm{L}$ of a $10 \mathrm{mg} / \mathrm{mL}$ solution; PEDGE: $1 \mu \mathrm{L}$ of a $2.5 \mathrm{mg} / \mathrm{mL}$ solution; invertase: $5 \mathrm{U}$; FDH: $5 \mathrm{U} ; \mathrm{v}=10 \mathrm{mV} / \mathrm{s} ; 0.1 \mathrm{M}$ phosphate buffer $\mathrm{pH} 7.0$; electrode diameter: $3 \mathrm{~mm}$ 


\subsection{Sucrose Biosensor}

Different amounts of the two enzymes were tested in order to optimize the sucrose-Os-polymer CNTP biosensor. Figure 4 shows the sucrose calibration graphs derived from the amperometric study by using an Os-polymer CNTP electrode with invertase and FDH directly wired to the Os-polymer hydrogel. The effect of enzyme amounts on the biosensor current response was studied in the range 2-10 U for both enzymes. The three curves showed the same trend: a linear part at the beginning and a deviation from linearity when higher sucrose concentrations are employed. This behaviour can be ascribed to a possible saturation of the enzyme active site. The current values gradually increase at increasing invertase and FDH amount loaded for relatively low amount used (from 2 to $5 \mathrm{U}$, as reported in curves a and b, Figure 4) but slightly decrease at higher enzyme amounts employed (more than $5 \mathrm{U}$, curve c, Figure 4). This result can be explained by taking into account the fact that the enzyme amount is a rate limiting factor at quite low enzyme amounts employed but at higher enzyme values used other factors started to limit the rate of the reaction. An amount of $5 \mathrm{U}$ of invertase and $5 \mathrm{U}$ of FDH showed the higher current response (curve b, Figure 4) and therefore $5 \mathrm{U}$ of FDH and $5 \mathrm{U}$ of inveratse were used to prepare the biosensor in further experiments.

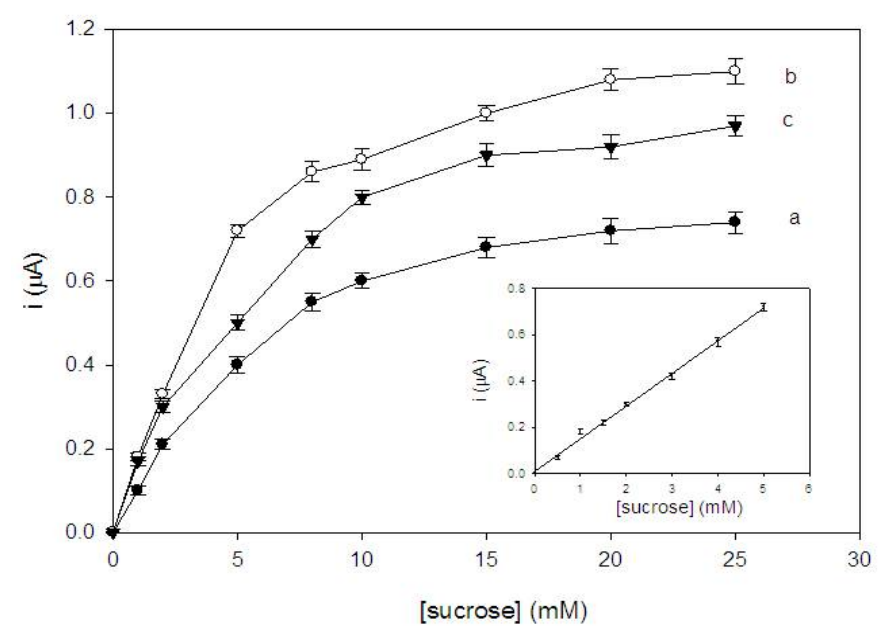

Figure 4. Calibration curves of the sucrose biosensor. Experimental conditions: inveratse-FDH amounts directly immobilized onto the Os-polymer hydrogel: 2U/2U (curve a); 5U/5U (curve b); 10U/10U (curve c); RSD\% values between 0.9 and 3.2\% ( $\mathrm{n}=5)$; Applied potential: $0.2 \mathrm{~V}(\mathrm{vs}$. $\mathrm{Ag} / \mathrm{AgCl})$. The inset shows the linear part of curve b. All other experimental conditions as in Figure 3

The low amount of both enzymes employed and the relatively high current response can be understood by the fact that the enzymes are now wired through the Os-polymer onto the surface of the CNTP electrode. The enzyme is immobilized into the hydrogel without large structural changes and without any significative loss of activity and at the same time, due to the high surface area of SWCNTs, a major exposure of the enzyme's catalytic sites is possible and also a large loading of both enzymes with a consequent enhancement of the amperometric signal.

The linear part of the sucrose calibration curve registered by the optimized biosensor is shown in the inset of Figure 4. A a good linear range is shown from 0.1 to $5 \mathrm{mM}$ with the following equation $\mathrm{y}=0.14 \mathrm{x}+1.03 \times 10^{-2}$ $(\mathrm{r}=0.9969, \mathrm{n}=6)$, where $\mathrm{y}$ indicates the current $(\mu \mathrm{A})$ and $\mathrm{x}$ the sucrose concentration $(\mathrm{mM})$. At higher sucrose concentrations the curve approaches a saturation value and starts to become nonlinear. The biosensor showed a good sensitivity of $1.98 \mu \mathrm{A} \mathrm{cm}{ }^{-2} \mathrm{mM}$ and a detection limit of about $2 \mu \mathrm{M}$, calculated with the following expression: 3S.D.a/b, with S.D.a the absolute standard deviation of the intercept and $b$ the slope of the calibration curve.

The response time of the biosensor was quite short, resulting of about $8 \mathrm{~s}$.

\subsection{Dependance of Biosensor Response on $\mathrm{pH}$ and Temperature}

In order to study the effect of different solution $\mathrm{pHs}$ on the sucrose biosensor response two different buffers were used and the $\mathrm{pH}$ ranges between 4 and 5.5 and between 6 and 7.5 in $0.1 \mathrm{M}$ acetate buffer and $0.1 \mathrm{M}$ phosphate buffer, respectively, were investigated. The biosensor maximum current response is registered in acetate buffer at 
$\mathrm{pH}$ 5.0, as clearly shown in Figure 5, and for this reason this $\mathrm{pH}$ was choosen for further experiments. At $\mathrm{pHs}$ higher than 6 a progressive decrease of the current response is observed until a loss of response of about $80 \%$ is registered when a $\mathrm{pH}$ value higher than 7 is used. This result is comparable with that reported in literature for FDH modified electrodes (Trivedi et al., 2009; Antiochia et al., 2004b) and for the optimum $\mathrm{pH}$ of the free enzymes, which resulted to be of 4.5 for both invertase and FDH (Ameyama, Shinagawa, Matsushita, \& Adachi, 1981; Schiweck, Clarke, \& Pollach, 2007).

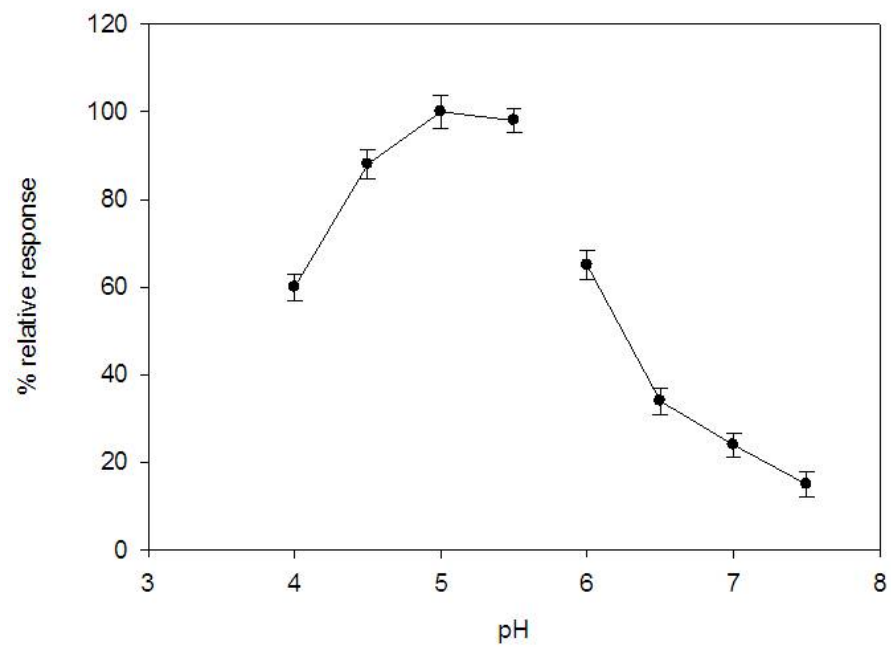

Figure 5. Dependance on the maximum biosensor response at a function of different pHs. [sucrose] $=5 \times 10^{-4} \mathrm{M}$; buffers employed: $0.1 \mathrm{M}$ acetate buffer, $4<\mathrm{pH}<5.5 ; 0.1 \mathrm{M}$ phosphate buffer, $6<\mathrm{pH}<7.5$. $\mathrm{RSD} \%$ values are between 3.0 and $4.0 \%(n=5)$. Other conditions as in Figure 4

We also studied the effect of the temperature of the buffer solution on the biosensor current response. The study was carried out in the range $10-40{ }^{\circ} \mathrm{C}$ and the results reported in Figure 6 . It is easy to observe that there is an initial increase of the biosensor relative response with increasing temperatures up to a maximum value at about $30{ }^{\circ} \mathrm{C}$ and successively a marked decrease. At higher temperautures there is in fact a possible thermal inactivation of $\mathrm{FDH}$, although the optimum temperature reported in literauture for free invertase enzyme is $60{ }^{\circ} \mathrm{C}$ (Schiweck, Clarke, \& Pollach, 2007). The temperature choosen for further experiments was $25^{\circ} \mathrm{C}$, at which only a $5 \%$ decrease of the maximum current response was obtained, for simplicity of operation being closer to room temperature. 


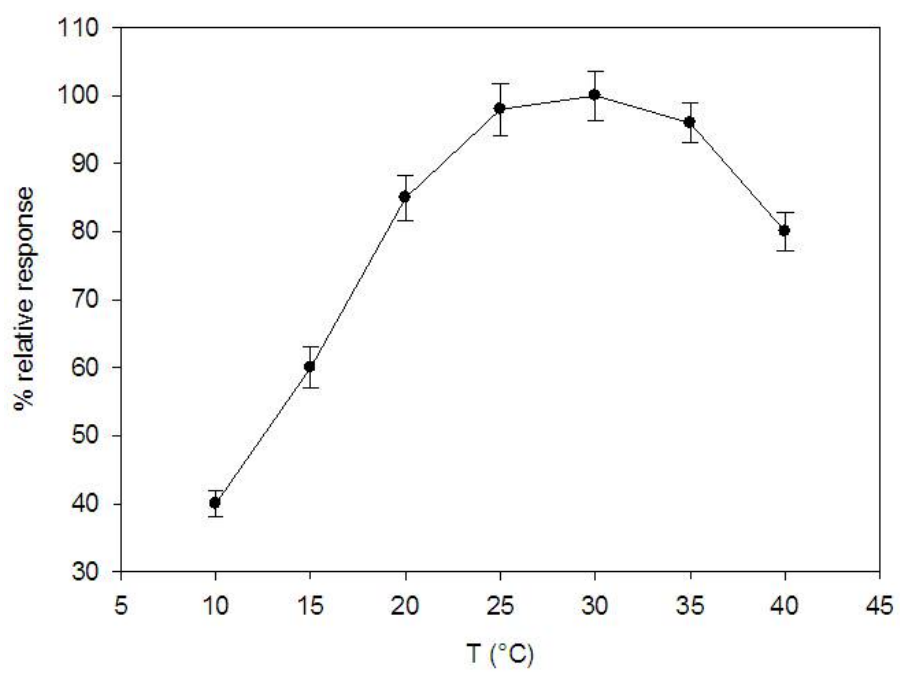

Figure 6. Dependance on the maximum biosensor response at a function of different temperatures. Sucrose $=$ $5 \times 10^{-4} \mathrm{M}$. RSD values between 2.2 and $4.0 \%(\mathrm{n}=5)$. Other conditions as in Figure 4

\subsection{Reproducibility of the Sucrose Biosensor}

The reproducibility of the sucrose biosensor was studied by using 5 different sensors. It resulted to be very good, with an RSD of $2.5 \%$ for a $0.5 \mathrm{mM}$ sucrose solution for $\mathrm{n}=5$, where $\mathrm{n}$ is the number of biosensors utilized in the test.

\subsection{Lifetime of the Sucrose Bisensor}

The storage stability and lifetime of the sucrose biosensor were also investigated. The current responses were consecutively measured for a $1 \mathrm{mM}$ sucrose solution every day for a period of 10 days. The sucrose biosensor was carefully stored at $4{ }^{\circ} \mathrm{C}$ when not in use under dry and wet storage conditions and the results are shown in Figure 7. The biosensor retains about $80 \%$ of its initial activity after 1 day of $8 \mathrm{~h} /$ day operation and only $15 \%$ after 10 days is kept under dry storage conditions. Otherwise under wet storage conditions, the biosensor keeps almost $100 \%$ of its original response after 3 days of $8 \mathrm{~h} /$ day operation and almost $85 \%$ after 10 days. Under wet conditions the study was extended up to 4 months and the biosensor resulted to be able to retain $80 \%$ of original response even up to such a long period. These excellent stability results obtained for the proposed biosensor are superior to most of the results reported in literature for amperometric biosensors for sucrose (Damar et al., 2011). A possible explanation of this extraordinary result is the fact that under wet conditions the biosensor is kept with cotton wet with buffer solution in a closed bottle thus allowing the maintenance of a higher water content in the immobilized hydrogel layer. 


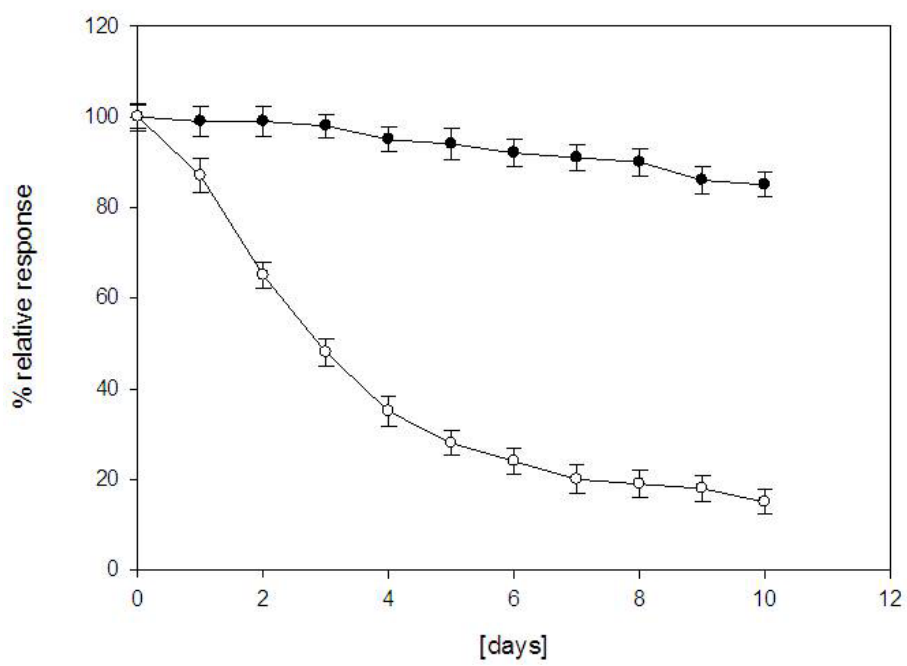

Figure 7. Lifetime of the sucrose biosensor stored at $4{ }^{\circ} \mathrm{C}$ under dry conditions (curve a) and wet conditions (curve b). RSD\% values between 2.8 and $3.5 \%(n=5)$. Other conditions as in Figure 4

\subsection{Selectivity of the Biosensor}

Interferences such as ascorbic acid, ethanol and other mono- and disaccharide compounds present in food such as glucose, lactose, galactose and maltose were investigated by adding equal amounts of the specific interferent and sucrose. As shown in Table 1, no significant influence was noted for each interferent specie studied. Only for ascorbic acid was reported a slight interference of about $7 \%$.

As for fructose, the sucrose biosensor is based on FDH and therefore reacts also towards fructose present in solution (Table 1). For this reason, all measurements of sucrose in real samples must be coupled with a measurement of the fructose concentration in the same sample by using the same sensor with inactive invertase and subtracting this current response from the total response of the sucrose biosensor.

Table 1. Effect of interfering compounds on sucrose response of the invertase-FDH-Os-polymer-CNTP sucrose biosensor. Interferents added $=500 \mu \mathrm{M}$

\begin{tabular}{ccc}
\hline Interfering compounds & [sucrose] $(\boldsymbol{\mu M})$ & Recovery (\%) \\
\hline Ascorbic acid & 460 & 93 \\
Ethanol & 490 & 98 \\
Glucose & 480 & 96 \\
Lactose & 470 & 94 \\
Galactose & 495 & 99 \\
Maltose & 485 & 97 \\
Fructose & 990 & 198
\end{tabular}

\subsection{Application on Food Analysis}

The developed invertase-FDH sucrose biosensor was utilized for the analysis of foodstuffs like commercial fruit juices. The sucrose content was calculated by using the calibration graph method. Each sample was analysed in five replicates. From a comparison of the results obtained with the proposed biosensor and those obtained using a commercial spectrophotometric enzymatic assay kit, it was possible to observe that there is a very good agreement between the results obtained with the two methods (Table 2). More precisly, the results obtained with the reference spectrophotometric kit show slightly higher values. It may be interesting to note that this can be explained by the fact that the kit is based on multienzymatic cascade reactions which can cause interferences with other compounds, in particular with other sugars. 
Table 2. Results for sucrose determination in real samples using the invertase-FDH biosensor and the reference enzymatic kit

\begin{tabular}{ccc}
\hline Sample & $\begin{array}{c}\text { [sucrose] }(\%)^{\mathbf{a}} \\
\text { sucrose biosensor }\end{array}$ & $\begin{array}{r}\text { [sucrose] (\%) } \\
\text { enzymatic } \boldsymbol{k i t}\end{array}$ \\
\hline Orange juice & $32.80 \pm 0.18$ & $34.15 \pm 0.24$ \\
Apple juice & $40.32 \pm 0.20$ & $43.16 \pm 0.30$ \\
Pineapple juice & $46.30 \pm 0.37$ & $48.14 \pm 0.25$ \\
Peach juice & $19.44 \pm 0.52$ & $21.70 \pm 0.38$ \\
Apple juice & $14.70 \pm 0.28$ & $16.98 \pm 0.34$ \\
Apricot juice & $60.12 \pm 0.55$ & $63.08 \pm 0.72$ \\
Mango juice & $21.32 \pm 0.64$ & $22.98 \pm 0.68$
\end{tabular}

${ }^{a}$ All measurements were repeated six times and reported as average \pm RSD $(n=6)$.

\section{Conclusion}

In this work the osmium redox polymer was successfully used for the modification of a CNTP electrode. The osmium redox polymer resulted to be able to shuttle the electrons between the immobilized enzyme and the single-walled CNTP electrode and was used also as a support for direct wiring of both invertase and FDH enzymes into the paste by using PEDGE as cross-linking agent. The modified electrode was used to develop a sucrose biosensor based on the immobilization of invertase and FDH. The biosensor assembly is simple, quick and not expensive. The sucrose biosensor showed the following analytical parameters: a good linear range, low detection limit $(2 \mu \mathrm{M})$, good sensitivity, high reproducibility, good stability and fast response time. Moreover, its response was not influenced by possible interfering species which can be present in food samples.

For these reasons this novel, cheap and "in situ" usable sucrose biosensor will form the basis for the development of an ideal commercial device for applications in food quality and safety control.

\section{Acknowledgments}

This work was supported by the following agencies: the Swedish Research Council and the Nanometer Consortium at Lund University.

\section{References}

Ameyama, M., Shinagawa, E., Matsushita, K., \& Adachi, O. (1981). D-Fructose dehydrogenase of Gluconobacter industrius: purification, characterization and application to enzymatic microdetermination of D-fructose. Journal of Bacteriology, 145, 814-823.

Ameyama, M., \& Adachi, O. (1982). D-Fructose dehydrogenase from Gluconobacter industrius, membrane-bound. Methods in Enzymology, 89, 154-159. http://dx.doi.org/10.1016/S0076-6879(82)89027-7

Antiochia, R., \& Palleschi, G. (1997). A tri-enzyme electrode probe for the sequential determination of fructose and glucose in the same sample. Analytical Letters, 30, 683-697. http://dx.doi.org/10.1080/00032719708006418

Antiochia, R., Lavagnini, I., Magno, F., Valentini, F., \& Palleschi, G. (2004a). Single-wall carbon nanotube paste electrodes: a comparison with carbon paste, platinum and glassy carbon electrodes via cyclic voltammetric data. Electroanalysis, 16, 1451-1458. http://dx.doi.org/10.1002/elan.200302971

Antiochia, R., Lavagnini, I., \& Magno, F. (2004b). Amperometrioc mediated carbon nanotube paste biosensor for fructose determination. Analytical Letters, 37, 1657-1669. http://dx.doi.org/10.1081/AL-120037594

Antiochia, R., Lavagnini, I., \& Magno, F. (2005). Electrocatalytic oxidation of NADH at single-wall carbon nanotube-paste electrodes: kinetic considerations for use of a redox mediator in solution and dissolved in the paste. Anal. Bioanal. Chem., 381, 1355-1458. http://dx.doi.org/10.1007/s00216-005-3079-6

Antiochia, R., \& Gorton, L. (2007). Development of a carbon nanotube paste electrode osmium polymer-mediated biosensor for determination of glucose in alcoholic beverages. Biosensor Bioelectronics, 
22, 2611-2617. http://dx.doi.org/10.1016/j.bios.2006.10.023

Antiochia, R., Vinci, G., \& Gorton, L. (2013). Rapid and direct determination of fructose in food: a new $\begin{array}{lllll}\text { osmium-polymer mediated biosensor. Food } & \text { Chem., 140, }\end{array}$ http://dx.doi.org/10.1016/j.foodchem.2012.11.023

AOAC International. (1995). Official Methods of Analysis (16th ed.). In P. A. Cunniff (Ed.), Arlington, (vol. II).

Bassi, A. S., Lee, E., \& Zhu, J. X. (1998). Carbon paste mediated, amperometric, thin film biosensors for fructose monitoring in honey. Food Research International, 31, 119-127. http://dx.doi.org/10.1016/S0963-9969(98)00071-4

Beutler, H. O. (1984). D-Fructose, Methods of Enzymatic Analysis, (3rd ed.), In H. U. Bergmeyer (Ed.), Verlag Chemie, Weinheim, (vol. VI), pp. 321-327.

Boyaci, I. H., \& Mutlu, M. (2002). Measurement of glucose, sucrose and lactose in food samples with enzyme-immobilized packed-bed column reactors integrated to an amperometric enzyme electrode. Nahrung/Food, 46 , 174-178. http://dx.doi.org/10.1002/1521-3803(20020501)46:3<174::AID-FOOD174>3.0.CO;2-L

Campuzano, S., Loaiza, O. A., Pedrero, M., Villena, F. J. M., \& Pingarron, J. M. (2004). An integrated bienzyme glucose oxidase-fructose dehydrogenase-tetrathiafulvalene-3-mercaptopropionic acid-gold electrode for the simultaneous determination of glucose and fructose. Bioelectrochemistry, 63, 199-206. http://dx.doi.org/10.1016/j.bioelechem.2003.10.019

Damar, K., \& Demirkol, D. O. (2011). Modified gold surfaces by poly(amidoamine)dendrimers and fructose $\begin{array}{llllll}\text { dehydrogenase for mediated fructose sensing. } & \text { Talanta, } & \text { 87, } & \text { 67. }\end{array}$ http://dx.doi.org/10.1016/j.talanta.2011.09.042

Davidson, V. L., \& Jones, L. H. (1991). Intermolecular electron transfer from quinoproteins and its relevance to biosensor technology. Analytical Chimica Acta, 249, 235-240. http://dx.doi.org/10.1016/0003-2670(91)87028-6

Eggins, B. R. (2002). Chemical Sensor and Biosensor. Wiley \& Sons Ed., London, UK.

Frattali, V. P. (1982). Food Carbohydrates. In D. R. Lineback \& G. E. Inglett (Eds.), AVI Press, Westport, pp. 37-50.

Garcia, C. A. B., Neto de Oliveira, G., Kubota, L. T., \& Grandin, I. A. (1996). A new amperometric biosensor for fructose using a carbon paste eletrode modified with silica gel coated with Meldola's Blue and fructose $\begin{array}{lllll}\text { 5-dehydrogenase. Journal Electroanalytical Chemistry, } & \text { 418, }\end{array}$ http://dx.doi.org/10.1016/S0022-0728(96)04775-4

Gooding, J. J. (2005). Nanostructuring electrodes with carbon nanotubes: a review on electrochemistry $\begin{array}{llll}\text { applications for } & \text { sensing. } & \text { Electrochimica } & \text { 3049-3060. }\end{array}$ http://dx.doi.org/10.1016/j.electacta.2004.08.052

Haghighi, B., Vaina, S., Alizadeh, F. N., Yigzaw, Y., \& Gorton, L. (2004). Prussian blue modified glassy carbon electrodes - study on operational stability and its application as a sucrose biosensor. Talanta, 64, 3-12. http://dx.doi.org/10.1016/j.talanta.2003.11.044

Heller, A. (1992). Electrical connection of enzyme redox centers to electrodes. The Journal of Physical Chemistry, 96, 3579-3587. http://dx.doi.org/10.1021/j100188a007

Heller, A., \& Feldman, B. (2008). Electrochemical glucose sensors and their applications in diabetes management. Chemical Reviews, 108, 2482-2505. http://dx.doi.org/10.1021/cr068069y

Kamitaka, Y., Tsujimura, S., Setoyama, N., Kajno, T., \& Kano, K. (2007). Fructose/dioxygen biofuel cell based on direct electron transfer-type bioelectrocatalysis. Physical Chemistry Chemical Physics, 9, 1793-1801. http://dx.doi.org/10.1039/b617650j

Kennedy, J. F., Pimentel, M. C. B., Melo, E. H. M., \& Lima-Filho, J. L. (2007). Sucrose biosensor as an alternative tool for sugarcane filed samples. $J$. of the Science of Food and Agriculture, 87, 2266-2271. http://dx.doi.org/10.1002/jsfa.2982 
Mastihuba, V., \& Leporisova, B. (2000). A new amperometric sucrose biosensor based on fructose dehydrogenase. Czech. J. Food Sci., 18, 121-123.

Majer-Baranyi, K., Adanyi, N., \& Varadi, M. (2008). Investigation of a multienzyme based amperometric biosensor for determination of sucrose in fruit juices. Eur. Food. Res. Technol., 228, 139-144. http://dx.doi.org/10.1007/s00217-008-0917-8

Mizutani, F., \& Yabuki S. (1997). Rapid determination of glucose and sucrose by an amperometric glucose-sensing electrode combined with an invertase/mutarotase-attached measuring cell. Bios. \& Bioelectr, 12, 1013-1020. http://dx.doi.org/10.1016/S0956-5663(97)00057-2

Mohammedi, H., Amine, A., Cosnier, S., \& Mousty, C. (2005). Mercury-enzyme inhibition assays with an amperometric sucrose biosensor based on a trienzymatic-clay matrix. Anal. Chim. Acta, 543, 143-149. http://dx.doi.org/10.1016/j.aca.2005.04.014

Moscone, D., Bernardo, R. A., Marconi, E., Amine, A., \& Palleschi, G. (1999). Rapid determination of lactulose in milk by microdialysis and biosensors. Analyst, 24, 325-329. http://dx.doi.org/10.1039/a808535h

Mutlu, M. (2011). Biosensors in Food Processing, Safety and Quality Control. CRC Press, Boca Raton, FL.

Paredes, P. A., Parellada, J., Fernandez, V. M., Katakis, I., \& Domínguez, E. (1997) Amperometric mediated carbon paste biosensor based on D-fructose dehydrogenase for the determination of fructose in food analysis. Biosensor \& Bioelectronics, 12, 1233-1243. http://dx.doi.org/10.1016/S0956-5663(97)00090-0

Parellada, J., Domínguez, E., \& Fernandez, V. M. (1996). Amperometric flow injection determination of fructose in honey with a carbon paste sensor based on fructose dehydrogenase. Analytical Chimica Acta, 330, 71-77. http://dx.doi.org/10.1016/0003-2670(96)87686-0

Piermarini, S., Volpe, G., Esti, M., Simonetti, M., \& Palleschi, G. (2011). Real time monitoring of alcoholic fermentation with low-cost amperometric biosensors. Food Chemistry, 127, 749-754. http://dx.doi.org/10.1016/j.foodchem.2011.01.008

Schiweck, H., Clarke, M., \& Pollach. (2007). Sugars, Ullmann's Encyclopedia of Industrial Chemistry. Wiley-VCH, Weinheim. http://10.1002/14356007.a25_345.pub2

Tasca, F., Gorton, L., Harreither, W., Haltrich, D., Ludwig, R., \& Nöll, G. (2009). Comparison of direct and mediated electron transfer for cellobiose dehydrogenase from Phanerochaete sordida. Analytical Chemistry, 81, 2791-2798. http://dx.doi.org/10.1021/ac900225z

Timur, S., Haghighi, B., Tkac, J., Pazarlioglu, N., Telefoncu, A., \& Gorton, L. (2006a). Electrical wiring of Pseudomonas putida and Pseudomonas fluorescens with osmium redox polymers. Bioelectrochemistry, 71, 38-45. http://dx.doi.org/10.1016/j.bioelechem.2006.08.001

Timur, S., Yigzae, Y., \& Gorton, L. (2006b). Electrical wiring of pyranose oxidase with osmium redox polymers. Sensor and Actuators B: Chemical, 13, 684-691. http://dx.doi.org/10.1016/j.snb.2005.07.017

Tkac, J., Vostiar, I., Sturdik, E., Gemeiner, P., Mastihuba, V., \& Annus, J. (2001). Fructose biosensor based on D-fructose dehydrogenase immobilised on a ferrocene-embedded cellulose acetate membrane. Analytical Chimica Acta, 439, 39-46. http://dx.doi.org/10.1016/S0003-2670(01)01021-2

Tran, M. C., \& Cahn, T. M. (1993). Biosensors. London, UK. Springer Ed.

Trivedi, U. B., Lakshminarayana, D., Kothari, I. L., Patel, P. B., \& Panchal, C. J. (2009). Amperometric fructose biosensor based on fructose dehydrogenase enzyme. Sensor and Actuators B: Chemical, 136, 45-51. http://dx.doi.org/10.1016/j.snb.2008.10.020

Valentini, F., Amine, A., Orlanducci, S., Terranova, M. L., \& Palleschi, G. (2003). Carbon nanotubes purification: preparation and characterization of carbon nanotube paste electrodes. Analytical Chemistry, 75, 5413-5421. http://dx.doi.org/10.1021/ac0300237

Wagner, G., \& Guilbault, G. (1994). Food Biosensor Analysis. In Marck Dekker (Ed.), New York, USA.

Wang, J. (2005). Carbon-Nanotube Based Electrochemical Biosensors: A Review. Electroanalysis, 17, 7-14. http://dx.doi.org/10.1002/elan.200403113 


\section{Copyrights}

Copyright for this article is retained by the author(s), with first publication rights granted to the journal.

This is an open-access article distributed under the terms and conditions of the Creative Commons Attribution license (http://creativecommons.org/licenses/by/3.0/). 